\title{
Association Between Asthma and Sensitization to Allergens of Dermatophagoides pteronyssinus
}

\author{
Vidal C'1, Lojo S², Juangorena M1', Gonzalez-Quintela A ${ }^{3}$
}

\author{
'Department of Allergy, Complejo Hospitalario Universitario de Santiago de Compostela, Santiago de \\ Compostela, Spain \\ 2Department of Biochemistry, Complejo Hospitalario Universitario de Santiago de Compostela, Santiago de \\ Compostela, Spain \\ ${ }^{3}$ Department of Medicine, Complejo Hospitalario Universitario de Santiago de Compostela, Santiago de \\ Compostela, Spain
}

J Investig Allergol Clin Immunol 2016; Vol. 26(5): 304-309

doi: 10.18176/jiaci.0048

\begin{abstract}
Background: Little is known about the role of molecular diagnosis in house dust mite (HDM) allergy. Objective: In this study, we investigated the association between the sensitization profile of adolescent and adult HDM-allergic patients and asthma in a region with high rates of exposure to HDM.

Methods: We conducted a cross-sectional study of 384 HDM-allergic patients (38.5\%, males; median age, 28 years). A total of 368 patients (95.8\%) had rhinitis, and $175(45.6 \%)$ had asthma. Specific lgE (slgE) to Dermatophagoides pteronyssinus, nDerp 1, rDer p 2, and rPen a 1 was measured in all patients. slgE to Lepidoglyphus destructor was measured in patients $(n=301)$ with a positive skin test result. Results: Significantly higher concentrations of slgE to Der $p 1$ and slgE to Der $p 2$ were observed in patients with asthma than in those without asthma. The proportion of asthmatic patients was higher among individuals who reacted $\left(\geq 0.35 \mathrm{kU} \mathrm{A}_{\mathrm{A}} / \mathrm{L}\right)$ to both Derp 1 and Der $\mathrm{p} 2$ (147/291, 50.5\%) than among those who reacted to only 1 allergen (either Derp 1 or Der $2,18 / 55,32.7 \%$ ) or neither allergen (10/38, $26.3 \%, P=.002)$. Reactivity to both allergens was associated with asthma after adjusting for age and sex $(0 \mathrm{R}, 2.87 ; 95 \% \mathrm{Cl}, 1.32-6.20)$. Higher concentrations of slgE to $L$ destructor were observed in patients with asthma than in patients without asthma. Tropomyosin slgE $\geq 0.35 \mathrm{kU}_{\mathrm{A}} / \mathrm{L}$ was detected in only 6 individuals $(1.6 \%)$.

Conclusions: L destructor may be a relevant allergen in high-exposure areas. Dual sensitization (ie, IgE to both Der p 1 and Der $\mathrm{p} 2$ ) may help to identify HDM-allergic patients who are at risk of asthma.
\end{abstract}

Key words: Dermatophagoides pteronyssinus. Der p 1. Der p 2. Lepidoglyphus destructor. Component-resolved diagnosis (CRD). Asthma.

\section{Resumen}

Antecedentes: El papel del diagnóstico molecular en la alergia a los ácaros no ha sido estudiado en profundidad.

Objetivo: Investigar el perfil molecular de sensibilización de pacientes adolescentes y adultos alérgicos a los ácaros del polvo doméstico y su relación con asma en una región en donde la exposición a los ácaros es importante.

Métodos: Estudio transversal en 384 pacientes alérgicos a los ácaros (38,5\% varones; edad media, 28 años) de los que 368 (95,8\%) padecían rinitis y 175 (45,6\%), asma. Se determinó la IgE específica (slgE) frente a D. pteronyssinus, nDer p 1, rDer p 2, y rPen a 1 en toda la muestra. Además, se midió la slgE frente a L. destructor en 301 con una prueba positiva frente a este ácaro.

Resultados: Los pacientes con asma presentaron niveles significativamente más altos de slgE frente a Derp 1 y a Der p 2 que aquellos que no padecían asma. La prevalencia de asma fue mayor en los pacientes con slgE positiva $\left(\geq 0,35 \mathrm{kU} \mathrm{A}_{\mathrm{A}} / \mathrm{L}\right)$ frente a ambos Der $\mathrm{p} 1$ y Der $\mathrm{p} 2$ $(147 / 291,50,5 \%)$ que entre los sujetos que tan solo presentaron slgE frente a uno de estos alérgenos (Der p 1 o Der p 2, 18/55, 32,7\%) o ninguno de ellos $(10 / 38,26,3 \%, p=0,002)$. La detección de slgE frente a ambos alérgenos se asoció con asma aún después de ajustar por edad o sexo (OR 2,87, 95\% Cl 1,32-6,20). Los pacientes con asma presentaron, asimismo, títulos más altos de lgE total y slgE frente a L. destructor-slgE. Solo 6 pacientes $(1,6 \%)$ presentaron niveles de slgE frente a la tropomiosina superiores a 0,35 kU $/ \mathrm{A}_{\mathrm{A}} \mathrm{L}$.

Conclusiones: L. destructor puede ser un alérgeno relevante en áreas en las que se encuentre presente. La doble sensibilización a Der 1 y Der 2 podría ser de utilidad para identificar sujetos con riesgo de asma.

Palabras clave: Dermatophagoides pteronyssinus. Der p 1. Der p 2. Lepidoglyphus destructor. Asma. Diagnóstico molecular. 


\section{Introduction}

The role of molecular diagnosis in house dust mite (HDM) allergy has received little attention in the literature. Today, however, the availability of natural and recombinant allergens of Dermatophagoides species makes it possible to investigate whether a specific molecular reactivity profile is associated with clinical manifestations in HDM-allergic individuals. Two recently published studies $[1,2]$ suggest that ISAC microarray-based determination of IgE against various Dermatophagoides components may be of value in defining the risk of developing asthma in children. In the first study, the authors followed 235 children with so-called complete mite sensitization - recognition of specific IgE (sIgE) against both Derp 1 and Derp 2 allergens - from age 5 to 11 years and found a higher risk of asthma, more frequent airway inflammation, and more severe exacerbations [1]. The second study was a cross-sectional study, in which the authors found that the risk of asthma was twice as high in children with sIgE to Der $\mathrm{p} 2$. The sIgE reactivity profile of older patients attracted less interest. In contrast, the authors focused more on the allegedly high degree of cross-reactivity between HDM and crustaceans through tropomyosin, although subsequent studies have shown a low degree of cross-reactivity [3]. The aim of the present study was to investigate the association between asthma and the sensitization profile of adolescent and adult HDM-allergic patients in a region with high rates of exposure to HDM.

\section{Patients and Methods}

\section{Study Population}

We conducted a cross-sectional study covering 384 consecutive HDM-allergic patients (38.5\% male; median age, 28 years [range, 14-73 years; IQR, 23-35 years]) seen in the Department of Allergy of Complejo Hospitalario Universitario de Santiago de Compostela, Santiago de Compostela, Spain between January and December 2010. Patients had been referred for the first time to our department from either primary care centers or hospitals for evaluation of a $\geq 1$-year history of symptoms of potential respiratory allergy (rhinitis, asthma, or both). The hospital has a catchment area of approximately 500000 inhabitants (95000 living in the city and its immediate environs and the remainder in a rural environment). The local weather is warm and humid, and mites are the most relevant inhalant allergens [4-6]. Patients were classified as having rhinitis $(n=368,95.8 \%)$ and asthma $(n=175,45.6 \%)$. Allergic rhinitis was diagnosed based on the recommendations of the ARIA 2008 update [4]. Thus, an association had to be demonstrated between a typical history of allergic symptoms (ie, rhinorrhea, sneezing, nasal pruritus, and bilateral obstruction with or without bilateral eye symptoms [itching, conjunctival hyperemia, and tearing]) and sensitization to IgE. Asthma was diagnosed based on the GEMA 2009 guidelines [5]; in addition, an increase in $\mathrm{FEV}_{1}$ greater than $12 \%$ and $200 \mathrm{~mL}$ after 4 successive $100-\mu \mathrm{g}$ puffs of a salbutamol inhaler with a spacer was required before patients with typical symptoms could be classified as asthmatic. A methacholine bronchial challenge test was needed to confirm bronchial hyperreactivity in 3 cases. Four patients had conjunctivitis only. Allergy to HDM was diagnosed by means of skin prick tests (SPTs) and positive serum $\operatorname{sigE}$ results $\left(\geq 0.35 \mathrm{kU}_{\mathrm{A}} / \mathrm{L}\right)$ for D pteronyssinus in patients with respiratory symptoms related to indoor dust exposure. Only patients sensitized to HDM and with symptoms of HDM were included. Patients with positive SPT results for Dermatophagoides also underwent SPTs for $L$ destructor, which is highly prevalent in the region [6-8].

\section{Main Determinations}

Total IgE was measured using latex-enhanced nephelometry in a BN-II System analyzer (Siemens). Allergen sIgE was measured using the ImmunoCAP-250 system (Thermo Fisher Scientific) and included sIgE against Dermatophagoides pteronyssinus, $\mathrm{nDer} \mathrm{p} 1$, rDer $\mathrm{p} 2$, and rPen a 1. L destructor SIgE was measured in patients with a positive SPT result. Following the manufacturer's instructions, sIgE levels $\geq 0.1 \mathrm{kU}_{\mathrm{A}} / \mathrm{L}$ were deemed positive, although for most analyses the classic $0.35 \mathrm{kU}_{\mathrm{A}} / \mathrm{L}$ threshold level was used.

\section{Statistical Analysis}

We used the chi-square test to compare proportions, the Mann-Whitney test to compare numerical variables between groups, and the Spearman rank test to assess correlations. Receiver operating characteristic (ROC) curves were constructed to compare the diagnostic performance of allergens. Logistic regression was used for multivariate analyses.

\section{Ethics}

The study was approved by the Institutional Review Board of Complejo Hospitalario Universitario de Santiago de Compostela and complied with the recommendations of the Declaration of Helsinki. Written informed consent was obtained from all participants.

\section{Results}

Prevalence of Sensitization and Levels of slgE to the Components of Dermatophagoides pteronyssinus According to Clinical Diagnosis

While the percentage of patients reacting to Der $p 1$ was higher than that of those reacting to Der $\mathrm{p} 2$ when the $\operatorname{sgE}$ cutoff level was set at $0.1 \mathrm{kU}_{\mathrm{A}} / \mathrm{L}(95.6 \%$ vs $85.7 \%)$, it was similar when the cutoff was set at $0.35 \mathrm{kU}_{\mathrm{A}} / \mathrm{L}(82.6 \%$ vs $83.3 \%$ Der p 1 and Der p 2, respectively). Concentrations of sIgE to Der 2 tended to be higher than those of $\operatorname{sIgE}$ to Der $\mathrm{p} 1$ (median, $9.49 \mathrm{kU}_{\mathrm{A}} / \mathrm{L}\left[1.65-29.1 \mathrm{kU}_{\mathrm{A}} / \mathrm{L}\right]$ vs median $6.68 \mathrm{kU}_{\mathrm{A}} / \mathrm{L}$ [0.59-24.4 $\left.\left.\mathrm{kU}_{\mathrm{A}} / \mathrm{L}\right]\right)$. A significant correlation was found between $\operatorname{sIgE}$ to Derp 1 and $\operatorname{sIgE}$ to Derp $2(\rho=0.812, P<.001)$, and between $\operatorname{sIgE}$ to Der $\mathrm{p} 1$ and $\operatorname{sIgE}$ to Der $\mathrm{p} 2$ and $\operatorname{sIgE}$ to $D$ pteronyssinus ( $\rho=0.888$ and 0.862 , respectively, $P<.001$ in both cases). Concentrations of $\operatorname{sIgE}$ to Der $\mathrm{p} 1$ and $\operatorname{sIgE}$ to Der $\mathrm{p} 2$ were not significantly different between patients with and without rhinitis (data not shown). In contrast, patients with asthma displayed significantly higher concentrations of $\operatorname{sigE}$ 
to Derp 1 and sIgE to Der 2 than did those without asthma (Table 1). Total serum IgE and sIgE to D pteronyssinus were also higher in patients with asthma (Table 1). The association between $\operatorname{sIgE}$ to Derp 1 and $\operatorname{sIgE}$ to Derp 2 and asthma was still present when the ratio of each allergen to either SIgE to D pteronyssinus or total IgE (Table 1) was considered in the analysis. Determination of sIgE to Derp 1 and $\operatorname{sigE}$ to Derp 2 performed equally well for the diagnosis of asthma when the allergens were analyzed individually. However, when the results were positive for both allergens, the risk of asthma was higher; hence, the proportion of asthmatic patients was higher among individuals who reacted $\left(\geq 0.35 \mathrm{kU}_{\mathrm{A}} / \mathrm{L}\right)$ to both Der $\mathrm{p} 1$ and Derp $2(147 / 291,50.5 \%)$ than among those who reacted

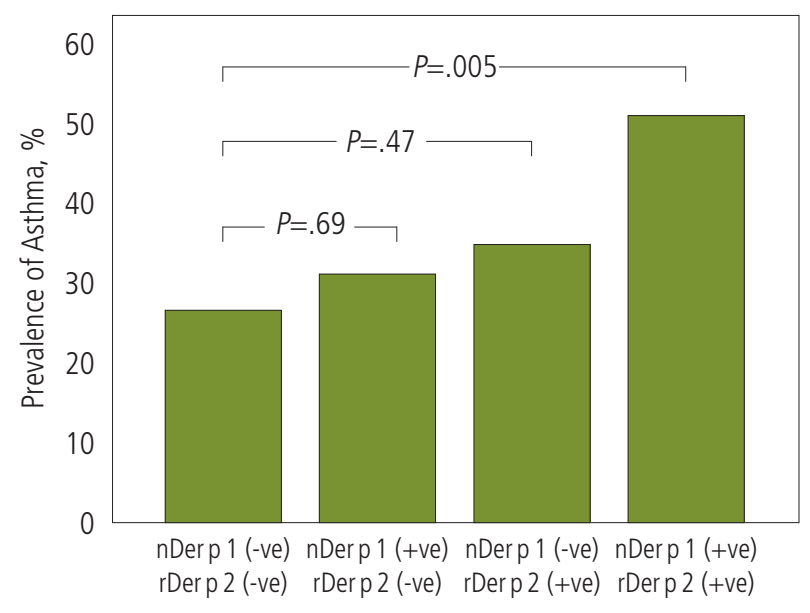

Figure. Prevalence of asthma in house dust mite-allergic individuals in relation to positivity $\left(\geq 0.35 \mathrm{kU}_{A} / \mathrm{L}\right)$ or negativity of specific lgE to Derp 1 and Derp 2. (+ve), positive; (-ve), negative. to only 1 allergen (Derp 1 or Derp 2, 18/55, 32.7\%) or neither allergen $(10 / 38,26.3 \%, P=.002$, Figure 1). Logistic regression analysis revealed that, whereas reactivity $(\geq 0.35 \mathrm{kA} / \mathrm{L})$ to only 1 allergen did not increase the risk of asthma with respect to reactivity to neither allergen (reference category; OR, 1.34 [95\%CI, 0.53-3.37]; $P=.52$ ), reactivity to both allergens significantly increased the risk of asthma after adjusting for age and sex (OR, 2.87; 95\%CI, 1.32-6.20).

Almost $81 \%$ of patients (310/384) were nonsmokers, but the proportion of smokers was slightly higher among patients with asthma than in those with rhinitis only $(23.4 \%$ vs $15.8 \%$, $P=.059)$. Nevertheless, levels of sIgE to both Derp 1 and Derp 2 were similar among smokers and nonsmokers (median of $6.66 \mathrm{kU}_{\mathrm{A}} / \mathrm{L}\left[0.56-34.8 \mathrm{kU} \mathrm{A}_{\mathrm{A}} / \mathrm{L}\right]$ vs $6.72 \mathrm{kU}_{\mathrm{A}} / \mathrm{L}\left[0.56-34.8 \mathrm{kU}_{\mathrm{A}} / \mathrm{L}\right.$; $P=.811]$ for Derp 1 and median of $9.47 \mathrm{kU}_{\mathrm{A}} / \mathrm{L}\left[2.11-32.6 \mathrm{kU}_{\mathrm{A}} / \mathrm{L}\right]$ vs $9.49 \mathrm{kU}_{\mathrm{A}} / \mathrm{L}\left[1.51-27.1 \mathrm{kU}_{\mathrm{A}} / \mathrm{L} ; P=.231\right]$ for Derp 2).

\section{Prevalence of Sensitization and Levels of slgE to Lepidoglyphus destructor and Association With the Components of Dermatophagoides Species}

SIgE to $L$ destructor was determined in 301 patients and proved to be positive in $\left(\geq 0.35 \mathrm{kU}_{\mathrm{A}} / \mathrm{L}\right)$ in 269 patients $(89.4 \%)$. The median value was $5.31 \mathrm{kU}_{\mathrm{A}} / \mathrm{L}\left(0.945-15.6 \mathrm{kU}_{\mathrm{A}} / \mathrm{L}\right)$. While the correlation between $\mathrm{sIgE}$ to $L$ destructor and SIgE to Derp 1 was low but statistically significant $(\rho=0.249 ; P<.001)$, the correlation between $\operatorname{sIgE}$ to $L$ destructor and $\operatorname{sigE}$ to Der $\mathrm{p} 2$ was somewhat higher $(\rho=0.400 ; P<.001)$. In addition, patients with asthma displayed higher concentrations of SIgE to $L$ destructor than did those without asthma (Table 1). Serum concentrations of SIgE to $L$ destructor were higher among patients living in a rural environment than among those living in an urban environment (Table 2). Conversely, concentrations of sIgE to Der 1 were higher in patients living in an urban environment (Table 2).

Table 1. slgE to Mites and Their Allergens and Total Serum IgE in House Dust Mite-Allergic Patients With and Without Bronchial Asthmaa,b

\begin{tabular}{|c|c|c|c|c|c|}
\hline & \multicolumn{4}{|c|}{ Bronchial Asthma } & \multirow[b]{3}{*}{$P$ Value } \\
\hline & \multicolumn{2}{|c|}{ Yes } & \multicolumn{2}{|c|}{ No } & \\
\hline & No. & Result & No. & Result & \\
\hline $\operatorname{sIgE}$ to $D$ pteronyssinus, $\mathrm{kU}_{\mathrm{A}} / \mathrm{L}$ & 175 & $40.2(11.4-85.8)$ & 209 & $11.7(3.90-29.2)$ & $<.001$ \\
\hline $\operatorname{sIgE}$ to $\mathrm{nDer} \mathrm{p} 1, \mathrm{kU}_{\mathrm{A}} / \mathrm{L}$ & 175 & $13.2(1.96-37.9)$ & 209 & $4.06(0.38-14.3)$ & $<.001$ \\
\hline $\operatorname{sIgE}$ to $\mathrm{rDer} \mathrm{p} 2, \mathrm{kU}_{\mathrm{A}} / \mathrm{L}$ & 175 & $19.6(5.41-43.9)$ & 209 & $5.76(0.51-13.7)$ & $<.001$ \\
\hline $\begin{array}{l}\text { Ratio of } \operatorname{sIgE} \text { to } \mathrm{nDer} \mathrm{p} 1 \text { to } \\
\mathrm{sIgE} \text { to } D \text { pteronyssinus }\end{array}$ & 175 & $0.41(0.23-0.63)$ & 209 & $0.32(0.09-0.56)$ & .014 \\
\hline $\begin{array}{l}\text { Ratio of sIgE rDer } \mathrm{p} 2 \text { to } \mathrm{sIgE} \text { to } \\
\text { D pteronyssinus }\end{array}$ & 175 & $0.54(0.34-0.78)$ & 209 & $0.42(0.20-0.68)$ & .007 \\
\hline $\operatorname{sIgE}$ to $L$ destructor, $\mathrm{kU}_{\mathrm{A}} / \mathrm{L}$ & 147 & $6.74(1.64-22.0)$ & 154 & $2.65(0.63-11.9)$ & $<.001$ \\
\hline Total serum IgE, IU/mL & 175 & $282.0(117.0-655.0)$ & 209 & $141.0(70.7-258.0)$ & $<.001$ \\
\hline Ratio of $\operatorname{sIgE}$ to $\mathrm{nDer} \mathrm{p} 1$ to total $\operatorname{IgE}$ & 175 & $0.055(0.013-0.091)$ & 209 & $0.035(0.002-0.090)$ & .039 \\
\hline Ratio of sIgE to rDer $\mathrm{p} 2$ to total IgE & 175 & $0.056(0.035-0.109)$ & 209 & $0.046(0.007-0.098)$ & .015 \\
\hline
\end{tabular}

Abbreviation: slgE, specific lgE.

aFigures are shown as median (IQR).

${ }^{b}$ Cases with slgE above the analytical limit $\left(100 \mathrm{kU}_{\mathrm{A}} / \mathrm{L}\right)$ were deemed to have $100 \mathrm{kU}_{\mathrm{A}} / \mathrm{L}$. 
Table 2. slgE to House Dust Mite and Its Allergens and Total Serum IgE in House Dust Mite-Allergic Patients Stratified According to Residence (Urban vs Rural $)^{a, b}$

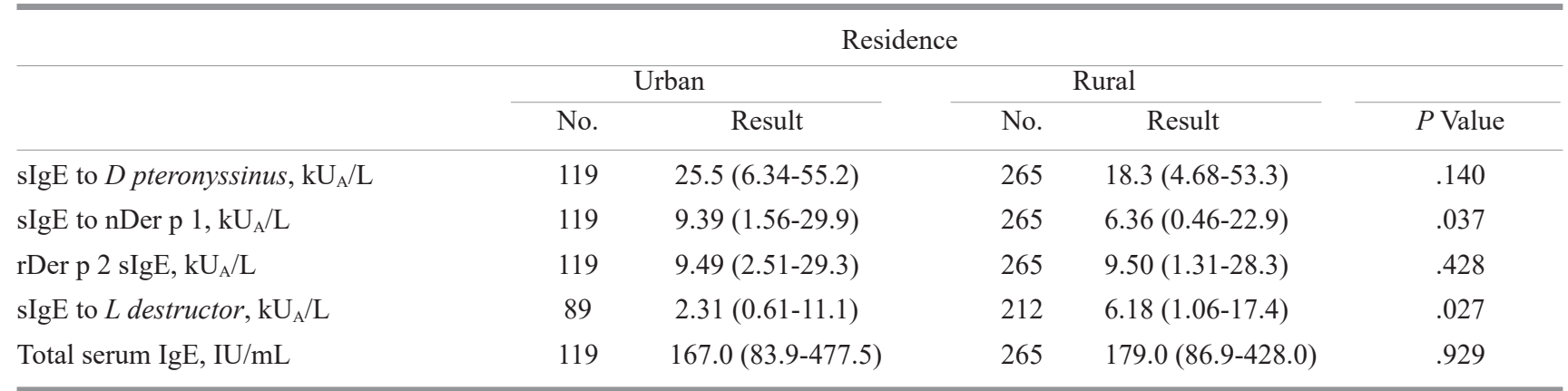

Abbreviation: slgE, specific lgE.

aFigures are shown as median (IQR). Patients living in the city of Santiago de Compostela (95000 inhabitants) were classified as living in an urban environment, and the remainder were classified as living in a rural environment.

${ }^{b}$ Cases with slgE above the analytical limit $\left(100 \mathrm{kU}_{\mathrm{A}} / \mathrm{L}\right)$ were deemed to have $100 \mathrm{kU}_{\mathrm{A}} / \mathrm{L}$.

\section{Prevalence of Sensitization and Levels of $\operatorname{sg} E$ to Tropomyosin}

SIgE to tropomyosin (Pen a 1) was determined in all 384 patients and was found to be $\geq 0.10 \mathrm{kU}_{\mathrm{A}} / \mathrm{L}$ in only 15 individuals $(3.9 \%)$ and $\geq 0.35 \mathrm{kU}_{\mathrm{A}} / \mathrm{L}$ in 6 individuals $(1.6 \%)$.

\section{Discussion}

The results of this study support the hypothesis that a more severe allergic respiratory disease is associated with higher levels of both total $\operatorname{IgE}[9,10]$ and specific sIgE [11] in sensitized individuals. Most of the patients studied had moderate to severe allergic rhinitis (ARIA 2008 update), since no patients with mild allergic rhinitis were referred from primary care to our Allergy Department. Our results suggest that dual sensitization-the presence of sIgE to both Der p 1 and Derp 2 - is associated with asthma among HDM-allergic patients. This observation is consistent with recent data from a longitudinal study indicating a higher risk of asthma in children with this pattern of sensitization [1]. It is also consistent with the findings of a recent case-control study, which showed that the more HDM allergens children recognize, the higher their risk of asthma [2]. Therefore, even though our results are more consistent with those reported by Custovic et al [1], the design of our study is more consistent with that of Resch et al [2], where the risk of asthma was found to be $>2$-fold higher in patients with $\operatorname{sigE}$ to $\operatorname{rDer} \mathrm{p} 2$. Nevertheless, the highest risk was found among patients with sIgE to rDer p 5, which was not measured in the present study because it is not available for ImmunoCAP [2]. In addition, Resch et al [2] did not evaluate the possible association with dual sensitization. Of note, we confirmed that dual sensitization was associated with asthma in older age groups (adolescents and adults), although we have no data on the possible association between this sensitization profile and the severity of asthma. We measured $\operatorname{sIgE}$ to both Der $\mathrm{p} 1$ and Der $\mathrm{p} 2$ using the conventional ImmunoCAP test instead of the ISAC test, which was the platform used by Custovic et al and Resch et al. Although ISAC can detect SIgE to a wide array of allergens, it is a semiquantitative analysis that is less accurate than ImmunoCAP for confirmation of HDM allergy [12]. With both platforms, Derp 1 is natural, whereas Derp 2 is recombinant, thus raising the issue of the ability of each type of allergen to recognize sIgE. Nonetheless, various studies have proven the utility of recombinant allergens from HDM in recognition of HDM-sensitized patients $[13,14]$. Moreover, the importance of dual sensitization was confirmed in an area of high HDM exposure and relevance in respiratory allergy (ie, Galicia in northeastern Spain) [6-8]. Consequently, the correlation between $\operatorname{sIgE}$ to Der $\mathrm{p} 1$ and $\operatorname{sIgE}$ to Der $\mathrm{p} 2$ was stronger than that observed in more general populations in Spain [15] [6-8]. It therefore seems reasonable to assume that different conclusions could be reached in other regions. In Germany and Austria, Derp 2 was shown to play a key role in the risk of asthma in children [2], whereas a recent study in China confirmed a relevant role for Derp 1 in the risk of asthma in both children and adults [16]. According to our data, the diagnostic performance of SIgE to Der 1 is similar to that of sIgE to Derp 2 in HDM-allergic adolescent and adult patients. Moreover, the stronger association with asthma was observed for simultaneous sensitization to both allergens rather than for isolated sensitization to either of them. From a mechanistic standpoint, the results of the present cross-sectional study in older individuals support the hypothesis that clinical phenotypes (allergic asthma, in this case) can be predicted by the molecular nature of IgE responses to individual allergen components earlier in life [2]. From a clinical standpoint, these results may be of importance, because dual sensitization could help to identify persons at risk of asthma among HDM-allergic patients in regions with similar levels of exposure to HDM. While the same could be said of Dermatophagoides farinae in areas where this species is more relevant, we focused our attention on D pteronyssinus because it is more representative of our area [8]. Higher concentrations of sIgE to Derp 1 were observed in patients living in an urban environment, and higher concentrations of $\operatorname{sIgE}$ to $L$ destructor in patients living in rural areas where this storage mite has been identified were 
more closely associated with livestock and storage facilities than with humidity [6]. From a diagnostic point of view, and even though a low degree of cross-reactivity has been reported between $L$ destructor and $D$ pteronyssinus, the availability of Lep d 2 would help to clarify the relevance of this mite in clinical terms. Further studies are needed to investigate whether sensitization to specific HDM allergens could affect the composition of immunotherapy in HDM-allergic patients.

Finally, the low frequency of sensitization to shrimp tropomyosin in our sample reflects observations in our daily clinical practice and findings from other authors from the same region [17], Germany [18], and China [16]. Our previous experience with sIgE to rDer p 10 in HDM-allergic patients (unpublished results) led us to choose shrimp tropomyosin as the source for identification of sensitization to tropomyosin in the study population. Nevertheless, the prevalence found was low. Therefore, although some mite allergens are shared by crustaceans, they seem to be of less importance in the present study than in others $[19,20]$. The fact that the study was performed in a region with both frequent exposure to HDM and high consumption of crustaceans may have influenced the results.

In conclusion, dual sensitization to Derp 1 and Derp 2 may help to identify persons at risk of asthma among HDM-allergic patients. $L$ destructor is a relevant allergen in areas with high exposure, such as the area where the study was performed.

\section{Funding}

The study was supported by a grant from the Carlos III Institute of Health (Spanish Ministry of Health, PI10/01870)

\section{Conflicts of Interest}

The authors declare that they have no conflicts of interest.

\section{References}

1. Custovic A, Sonntag HJ, Buchan IE, Belgrave D, Simpson A, Prosperi MC. Evolution pathways of IgE responses to grass and mite allergens throughout childhood. J Allergy Clin Immunol. 2015;136:1645-52. doi: 10.1016/j.jaci.2015.03.041

2. Resch $Y$, Michel S, Kabesch M, Lupinek C, Valenta R, Vrtala $S$. Different IgE recognition of mite allergen components in asthmatic and nonasthmatic children. J Allergy Clin Immunol. 2015;136:1083-91. doi: 10.1016/j.jaci.2015.03.024

3. Arlian LG, Morgan MS, Vyszenski-Moher DL, Sharra D. Crossreactivity between storage and dust mites and between mites and shrimp. Exp Appl Acarol. 2009;47:159-72. doi: 10.1007/ s10493-008-9199-x

4. Bousquet J, Khaltaev N, Cruz AA, Denburg J, Fokkens WJ, Togias A, Zuberbier T, Baena-Cagnani CE, Canonica GW, van Weel C, Agache I, Aït-Khaled N, Bachert C, Blaiss MS, Bonini $S$, Boulet LP, Bousquet PJ, Camargos P, Carlsen KH, Chen $Y$, Custovic A, Dahl R, Demoly $P$, Douagui $H$, Durham $S R$, van Wijk RG, Kalayci O, Kaliner MA, Kim YY, Kowalski ML, Kuna P, Le LT, Lemiere C, Li J, Lockey RF, Mavale-Manuel S, Meltzer
EO, Mohammad Y, Mullol J, Naclerio R, O'Hehir RE, Ohta K, Ouedraogo S, Palkonen S, Papadopoulos N, Passalacqua G, Pawankar R, Popov TA, Rabe KF, Rosado-Pinto J, Scadding GK, Simons FE, Toskala E, Valovirta E, van Cauwenberge P, Wang DY, Wickman M, Yawn BP, Yorgancioglu A, Yusuf OM, Zar H, Annesi-Maesano I, Bateman ED, Ben Kheder A, Boakye DA, Bouchard J, Burney P, Busse WW, Chan-Yeung M, Chavannes NH, Chuchalin A, Dolen WK, Emuzyte R, Grouse L, Humbert $M$, Jackson $C$, Johnston SL, Keith PK, Kemp JP, Klossek JM, Larenas-Linnemann D, Lipworth $B$, Malo JL, Marshall GD, Naspitz C, Nekam K, Niggemann B, Nizankowska-Mogilnicka E, Okamoto Y, Orru MP, Potter $P$, Price $D$, Stoloff SW, Vandenplas O, Viegi G, Williams D; World Health Organization; GA(2)LEN; AllerGen. Allergic Rhinitis and its Impact on Asthma (ARIA) 2008 update (in collaboration with the World Health Organization, GA(2) LEN and AllerGen). Allergy. 2008;63 Suppl 86:8-160. doi: 10.1111/j.1398-9995.2007.01620.x

5. GEMA 2009. Spanish asthma management guide. J Investig Allergol Clin Immunol. 2010;20 Suppl 1:9-18.

6. Vidal C, Chomón B, Pérez-Carral C, Gonzalez-Quintela A. Sensitization to Lepidoglyphus destructor, Tyrophagus putrescentiae, and Acarus siro in patients allergic to house dust mites (Dermatophagoides spp.). J Allergy Clin Immunol. 1997; 100:716-8.

7. Vidal C, Boquete $O$, Gude F, Rey J, Meijide LM, FernándezMerino MC, Gonzalez-Quintela A. High prevalence of storage mite sensitization in a general adult population. Allergy. 2004;59:401-5.

8. Boquete $\mathrm{M}$, Iraola V, Fernández-Caldas $\mathrm{E}$, Arenas Villaroel L, Carballada FJ, González de la Cuesta C, López Rico MR, Nuñez Orjales R, Parra A, Soto Mera MT, Varela S, Vidal C. House dust mite species and allergen levels in Galicia, Spain: a crosssectional, multicenter, comparative study. J Investig Allergol Clin Immunol. 2006;16:169-76.

9. Dávila I, Valero A, Entrenas LM, Valveny $N$, Herráez $L$, on behalf of the SIGE Study Group. Relationship between serum total $\lg \mathrm{E}$ and disease severity in patients with allergic asthma in Spain. J Investig Allergol Clin Immunol. 2015;25:120-7.

10. Custovic A, Simpson A. The role of inhalant allergens in allergic airway disease. J Investig Allergol Clin Immunol. 2012;22:393401.

11. Erwin EA, Rönmark $E$, Wickens $K$, Pernazowski MS, Barry $D$, Lündback B, Crane J, Platts-Mills ThAE. Contribution of dust mite and cat specific lgE to total IgE: relevance to asthma prevalence. J Allergy Clin Immunol. 2007;119:359-65.

12. Wohrl S, Vigl K, Zehetmayer S, Hiller R, Jarisch R, Prinz $M$, Stingl G, Kopp T. The performance of a component-based allergen-microarray in clinical practice. Allergy. 2006;61:6339.

13. Weghofer M, Thomas WR, Pittner G, Horak F, Valenta R, Vrtala S. Comparison of purified Dermatophagoides pteronsyssinus allergens and extract by two-dimensional immunoblotting and quantitative immunoglobulin $\mathrm{E}$ inhibitions. Clin Exp Allergy. 2005;35:1384-91.

14. Pittner G, Vrtala S, Thomas WR, Weghofer M, Kundi M, Horak F, Kraft D, Valenta R. Component-resolved diagnosis of housedust mite allergy with purified natural and recombinant mite allergens. Clin Exp Allergy. 2004;34:597-603. 
15. Barber D, Arias J, Boquete M, Cardona V, Carrillo T, Gala G, Gamboa P, García-Robaina JC, Hernández D, Sanz ML, Tabar Al, Vidal C, Ipsen H, de la Torre F, Lombardero M. Analysis of mite allergic patients in a diverse territory by improved diagnostic tools. Clin Exp Allergy. 2012;42:1129-38. doi: 10.1111/j.1365-2222.2012.03993.x.

16. Zeng G, Luo W, Zheng P, Wei N, Huang H, Sun B, Zhao X. Component-resolved diagnostic study of Dermatophagoides pteronyssinus major allergen molecules in a Southern Chinese cohort. J Investig Allergol Clin Immunol. 2015;25:343-51.

17. Boquete M, Iraola V, Morales M, Pinto H, Carballada F, Carnés J. Seafood hypersensitivity in mite sensitized individuals: is tropomyosin the only responsible allergen? Ann Allergy Asthma Immunol. 2011;106:223-9. doi: 10.1016/j.anai.2010.11.014.

18. Becker $S$, Gröger $M$, Canis $M$, Pfrogner $E$, Kramer MF. Tropomyosin sensitization in house dust mite allergic patients. Eur Arch Otorhinolaryngol. 2012;269:1291-6. doi: 10.1016/j. anai.2010.11.014.

19. Purohit A, Shao J, Degreef JM, van Leeuwen A, van Ree R, Pauli $\mathrm{G}$, de Blay F. Role of tropomyosin as a cross-reacting allergen in sensitization to cockroach in patients from Martinique
(French Caribbean island) with a respiratory allergy to mite and a food allergy to crab and shrimp. Eur Ann Allergy Clin Immunol. 2007;39:85-8.

20. Fernandes J, Reshef A, Patton L, Ayuso R, Reese G, Leher SB. Immunoglobulin $\mathrm{E}$ antibody reactivity to the major shrimp allergen, tropomyosin, in unexposed Orthodox Jews. Clin Exp Allergy. 2003;33:965-61.

Manuscript received December 8, 2015; accepted for publication, January 7, 2016.

\section{- Carmen Vidal}

Department of Allergy

Complejo Hospitalario Universitario de Santiago 15706 Santiago de Compostela, Spain

E-mail: carmen.vidal.pan@sergas.es 